\title{
PENGARUH LINGKUNGAN KERJA, INSENTIF, KOMUNIKASI DAN SENIORITAS TERHADAP SEMANGAT KERJA KARYAWAN
}

\section{EFFECT OF WORK ENVIRONMENT, INCENTIVES, COMMUNICATION AND SENIORITY ON WORK SPIRIT OF EMPLOYEES}

\author{
Eko Murtisaputra ${ }^{1}$, Sri Langgeng Ratnasari ${ }^{2}$ \\ Program Studi Magister Manajemen Program Pascasarjana Universitas Riau Kepulauan \\ ekom16278@gmail.com
}

\begin{abstract}
Abstrak
Penelitian ini bertujuan untuk mengetahui pengaruh antara lingkungan kerja, insentif, komunikasi dan senioritas terhadap semangat kerja karyawan Ramayana Department Store Cabang Kota Tanjungpinang. Jenis penelitian yang digunakan adalah penelitian asosiatif dengan metode kuesioner, dan studi pustaka yang dilakukan secara sistematik. Sampel pada penelitian ini yaitu sebanyak 89orang karyawan serta pengolahan data menggunakan program komputer SPSS versi 2.00. Penelitian ini telah memenuhi syarat validitas dan reliabilitas. Analisis data yang digunakan dalam penelitian ini adalah uji asumsi klasik, regresi linier berganda, uji hipotesis dan analisis koefisien determinasi. Hasil dari penelitian ini yaitu berdasarkan pengujian secara Parsial ternyata hasil penelitian membuktikan bahwa variabel lingkungan kerja (X1), insentif (X2), komunikasi (X3), dan senioritas (X4) mempunyai pengaruh yang signifikan terhadap semangat, hal ini dapat dilihat dari variabel lingkungan kerja yang memiliki nilai $t_{\text {hitung }}>t_{\text {tabel }}(3.274>1.988)$, kemudian variabel insentif memilihi nilai $t_{\text {hitung }}>t_{\text {tabel }}(3.724>1.988)$, dan variabel komunikasi memiliki nilai $t_{\text {hitung }}>$ $t_{\text {tabel }}(2.785>1.988)$, dan variabel Senioritas memiliki nilai $t_{\text {hitung }}>t_{\text {tabel }}(2.075>1.988)$. Berdasarkan pengujian simultan ternyata hasil penelitian menunjukan nilai $F_{\text {hitung }}$ sebesar 50.845 , nilai $F_{\text {tabel }}$ sebesar karena nilai $F_{\text {hitung }}>F_{\text {tabel }}(50.845>2.71)$ sehingga dapat disimpulkan bahwa variabel bebas (lingkungan kerja, insentif, komunikasi dan senioritas) secara bersama-sama berpengaruh terhadap semangat kerja karyawan Ramayana Departement Store Cabang Kota Tanjungpinang. Hasil pengujian determinasi $\left(R^{2}\right)$ menunjukan bahwa nilai adjusted $R$ sequare koefisien determinasinya $=0.694$ (69.4\%). Angka tersebut menunjukan bahwa variabel independen yaitu lingkungan kerja, insentif, komunikasi, dan senioritas memberi sumbangan pengaruh kepada variabel dependen yaitu semangat kerja sebesar $69.4 \%$ sedangkan sisanya $30.6 \%$ dipengaruhi oleh variabel lainnya yang tidak diteliti dalam penelitiaan ini.
\end{abstract}

\section{Kata Kunci: Lingkungan Kerja, Insentif, Komunikasi, Senioritas, Semangat Kerja}

\begin{abstract}
This study aims to determine the influence between work environment, incentives, communication and seniority to employee morale Ramayana Department Branch Tanjungpinang City. The type of research used is associative. The research method used in this study using questionnaire method, and literature study conducted systematically. The sample in this study 89orang employees. Data processing using computer program SPSS version 2.00. This research has fulfilled the requirements of validity and reliability. Data analysis used in this research is classical assumption test, multiple linear regression, hypothesis test and coefficient analysis of determinationThe result of this research is based on Persial test. The result of this research shows that work environment (X1), incentive (X2), communication (X3), and seniority (X4) have significant influence to the spirit, it can be seen from environment variable $t_{\text {count }}>t_{\text {table }}(3.274>1.988)$, then the incentive variable has a value $t_{\text {count }}>t_{\text {table }}(3,724>1,988)$, and the communication variable has the value of $t_{\text {count }}>t_{\text {table }}(2.785>1.988)$, and the Seniority variable has the value of $t_{\text {count }}>t_{\text {table }}$ the value of $t_{\text {count }}>t_{\text {table }}$ (2.075> 1.988). Based on the simultaneous test, the result of the research shows that the value of Fcount is 50,845 , the Ftable value is equal to the value of $F_{\text {count }}>F_{\text {table }}(50.845>2.71)$ so it can be concluded that the independent variables (work environment, incentive, communication and seniority) together influence the employee morale Ramayana Department Store Tanjungpinang City Branch. The test results of determination $(R 2)$ obtained menunjjukan adjusted $R$ sequare determination coefficient $=0.694(69.4 \%)$. These figures show that the independent variables ie work environment, incentives, communication, and seniority contribute influence to the dependent variable of work morale of $69.4 \%$ while the remaining $30.6 \%$ is influenced by other variables not examined in this research.
\end{abstract}

Keywords: Work Environment, Incentives, Communication, Seniority, Work Spirit 


\section{PENDAHULUAN}

Dalam era globalisasi perusahaan-perusahaan dituntut untuk dapat lebih bersaing. Perusahaan harus memiliki keunggulan dan daya saing, sehingga mampu bertahan di antara perusahaan-perusahaan lain. Keberhasilan suatu perusahaan sangat dipengaruhi oleh karyawannya.Sumber daya manusia merupakan faktor yang sangat penting dalam sebuah perusahaan baik perusahaan dalam skala besar maupun kecil. Dalam perusahaan berskala besar, sumber daya manusia dipandang sebagai unsur yang sangat menentukan dalam proses pengembangan usaha. Peran sumber daya manusia menjadi semakin penting dalam suatu organisasi untuk mencapai target yang telah ditentukan oleh perusahaan. Perkembangan dunia usaha akan terealisasi apabila ditunjang oleh sumber daya manusia yang berkualitas.

Mall merupakan pusat perbelanjaan yang terdiri dari banyk jenis kebutuhan yang diperlukan oleh masyarakat. Mall juga tempat yang dikunjungi oleh masyarakat untuk membeli atau melihat dan membandingkan barang-barang dalam memenuhi kebutuhan ekonomi sosial masyarakat serta memberikan kenyamanan dan keamanan berbelanja bagi pengunjung. Ramayana Department Store Cabang Kota Tanjungpinang adalah salah satu pusat perbelanjaan atau Mall yang terletak di Jl. Wiratno Kota Tanjungpinang. Ramayana Department Store cabang kota Tanjungpinang didirikan pada tanggal 26 Mei 2002.

Menurut Leighton (Saputra, Hendriani, \& Amsal, 2014) semangat kerja adalah kemauan sekelompok orang untuk bekerja sama dengan giat dan konsekuen dalam mengejar tujuan bersama. Semangat kerja membuat tugas yang dilaksanakan oleh pimpinan cepat dengan mudah terselesaikan dan hasilnya pun lebih maksimal karena karyawan semangat dan antusias dalam melaksanakan pekerjaan tersebut.

Seperti yang pernah terjadi di Ramayan karena karyawan tersebut kurang semangat dalam bekerja akhirnya pihak perusahaan tidak memperpanjang kontrak karyawan tersebut. Adapun faktor- faktor yang mempengaruhi semangat kerja menurut Nitisemito (Widani, 2017) adalah kepemimpinan, motivasi, komunikasi, hubungan manusiawi, kompensasi dan lingkungan kerja.

Permasalahan yang terjadi pada lingkungan kerja karyawan Ramayana yaitu jarangnya dihidupkan AC atau alat pendingin sehingga ketika hari sedang panas, karyawan sering berkipas dengan menggunakan kertas dll, sehingga mengganggu kinerja dalam bertugas, seperti badan kita penuh dengan keringat, penampilan jadi berubah karena faktor dari keringat tersebut. Kemudian bangunannya pun sudah mulai rusak seperti kramiknya sudah banyak 
yang pecah, jalannya pun sudah banyak yang bergelombang faktor dari lamanya bangunan tersebut berdiri dan belum terjadi renovasi sehingga membuat karyawan kurang nyaman dalam bekerja.

Di Ramayana pemberian insentif dilakukan selama sebulan sekali dan diberikan tidak bersamaan dengan gaji. Karyawan tersebut mendapat insentif apabila karyawan tersebut mencapai taget yang telah ditentukan sebelumnya oleh toko, tetapi untuk mendapatkan insentif pun harus memenuhi syarat-syarat yang telah ditentukan seperti pencapaian target baik itu target toko yang telah ditentukan oleh Ramayana pusat dan target konter yang ditentukan sendiri oleh pimpinan Ramayana cabang Tanjungpinang dengan berkoordinasi dengan para staf. Tetapi sekarang karna perekonomian menurun maka dalam pemberian insentif untuk divisi product dan divisi supermarket diadakan kompetisi bagi konter yang dapat mencapai target yang telah ditentukan dan memiliki jumlah pendapatan lebih besar dibandingkan yang lain maka konter tersebut mendapatkan insentif. Sedangkan untuk divisi consignment pemberian insentif tetap dilakukan sesuai dengan pencapain target yang telah ditentukan tetapi dalam perhitungan insentifnya berbeda-beda antar konter sesuai dengan peraturan yang telah ditetapkan.

Dalam permasalahan insentif masih ada karyawan yang mengeluhkan pemberian target yang tidak sesuai dengan keadaan konter seperti barang yang ada di konter tidak banyak atau kurang di sukai oleh konsumen sehingga sulit karyawan tersebut untuk mencapai target yang ditentukan dan akhirnya tidak mendapatkan insentif.

Selain itu ada juga faktor lain yang mempengaruhi semangat kerja karyawan yaitu komunikasi. Adapun komunikasi yang terjadi di Ramayana Department Store Cabang Kota Tanjungpinang merupakan komunikasi ke bawah yang dilakukan pimpinan kepada bawahannya, berupa perintah, instruksi tugas, dan informasi, sedangkan komunikasi keatas dari karyawan ke pimpinan hanya sesekali dilakukan bila karyawan membutuhkan informasi dan dalam rapat yang dilakukan bersama karyawan pun jarang karyawan memberikan masukan hanya beberapa orang saja. Hal ini disebabkan karena kurang beraninya bawahan dalam menyampaikan kritik dan saran kepada atasannya

Selain dari lingkungan kerja, insentif, komunikasi faktor lain yang juga mempengaruhi semangat kerja adalah senioritas. Dalam Ramayana ada permasalahan yang berhubungan dengan senioritas yaitu, terjadinya perkelahian sesama karyawan karena hasut mengasut atau karna adanya selisih paham antara karyawan senior dan junior, karena karyawan senior 
merasa sudah lama bekerja dan sudah paham tentang pekerjaannya diperusahaan tersebut sehingga ketika junior memberikan komentar atau memberikan saran kepada senior, senior merasa digurui, sehigga kadang terjadi perselisihan atau perkelahian saling ejek mengejek, sering membicarakan senior atau juniornya kepada orang lain atau karyawan lain.

Berdasarkan masalah-masalah tersebut, maka dilakukan penelitian dengan judul: "Pengaruh Lingkungan kerja, Insentif, Komunikasi dan Senioritas Terhadap Semangat Kerja Karyawan".

\section{Rumusan Masalah}

Rumusan masalah dalam penelitian ini adalah:

1. Apakah lingkungan kerja berpengaruh terhadap semangat kerja karyawan Ramayana Department Store Cabang Kota Tanjungpinang?

2. Apakah insentif berpengaruh terhadap semangat kerja karyawan Ramayana Department Store Cabang Kota Tanjungpinang?

3. Apakah komunikasi berpengaruh terhadap semangat kerja karyawan Ramayana Department Store Cabang Kota Tanjungpinang?

4. Apakah senioritas berpengaruh terhadap semangat kerja karyawan Ramayana Department Store Cabang Kota Tanjungpinang?

5. Apakah Lingkungan kerja, insentif, komunikasi, dan senioritas sama-sama berpengaruh terhadap semangat kerja karyawan Ramayana Department Store Cabang Kota Tanjungpinang?

\section{Batasan Masalah}

Agar pembahasan lebih terarah dan tidak menyimpang dari permasalahan yang ada, maka peneliti akan membatasi pembahasan mengenai pengaruh lingkungan kerja, insentif, komunikasi dan senioritas terhadap semangat kerja karyawan. Batasan masalahnya yaitu yang dibahas hanya mengenai lingkungan kerja fisik dan hanya mengenai insentif material.

\section{Tujuan Penelitian}

Tujuan dilakukannya penelitian ini adalah:

1. Untuk mengetahui pengaruh lingkungan kerja terhadap semangat kerja karyawan Ramayana Department Store Cabang Kota Tanjungpinang.

2. Untuk mengetahui pengaruh insentif terhadap semangat kerja karyawan Ramayana Department Store Cabang Kota Tanjungpinang. 
3. Untuk mengetahui pengaruh komunikasi terhadap semangat kerja karyawan Ramayana Department Store Cabang Kota Tanjungpinang.

4. Untuk mengetahui pengaruh senioritas terhadap semangat kerja karyawan Ramayana Department Store Cabang Kota Tanjungpinang.

5. Untuk mengetahui pengaruh lingkungan kerja, insentif, komunikasi, dan Senioritas terhadap semangat kerja karyawan Ramayana Departmen Store Cabang Kota Tanjungpinang

\section{TINJAUAN PUSTAKA}

\section{Semangat Kerja}

Semangat kerja sering dihubungkan dengan sikap atau tingkah laku karyawan terhadap pekerjaan yang mereka lakukan dengan memperhatikan dan mengamati sikap dan tingkah laku karyawan terhadap pekerjaannya dapat diketahui sampai sejauh mana karyawan tersebut telah bekerja secara produktif, dimana produktivitas yang tinggi dapat dicapai karyawan yang mempunyai semangat kerja yang tinggi. Menurut (Nitisemito, 2010) semangat kerja adalah suatu iklim atau suasana kerja yang terdapat di dalam suatu organisasi yang menunjukan rasa kegairahan di dalam melaksanakan pekerjaan dan mendorong mereka untuk bekerja secara lebih baik dan lebih produktif.

Adapun indikator untuk mengukur semangat kerja menurut (Nitisemito, 2010) adalah

\section{Absensi}

2. Kerja sama

3. Kepuasan kerja

4. Kedisiplinan.

\section{Lingkungan Kerja}

Lingkungan kerja mempunyai pengaruh terhadap karyawan di perusahaan dalam usaha untuk menyelesaikan tugas-tugas yang dibebankan kepadanya, yang pada akhirnya berpengaruh terhadap semangat kerja karyawan tersebut. Lingkungan kerja yang baik dan memuaskan karyawan tentu akan meningkatkan kinerja karyawan itu sendiri menjadi lebih maksimal dan optimal dalam bekerja. Lingkungan kerja yang baik juga akan mendorong timbulnya semangat kerja karyawan. Dengan semangat kerja yang tinggi, karyawan akan dapat bekerja dengan perasaan senang dan bergairah sehingga mereka akan berprestasi dalam pekerjaanya. Menurut (Tulenan, 2015) lingkungan kerja adalah tempat dimana karyawan bekerja atau tempat di mana semua kegiatan kerja berlangsung. 
Menurut (Jain \& Kaur, 2014) indikator lingkungan kerja dapat dibagi menjadi 3 komponen yaitu :

1. Lingkungan kerja fisik
a. Ventilasi dan suhu
b. Kebisingan
c. Infrastruktur dan interior
d. fasilitas

2. Lingkungan psikologis

3. Lingkungan sosial

\section{Insentif}

Insentif merupakan salah satu penghargaan yang dikaitkan dengan prestasi kerja.Semakin tinggi prestasi kerja maka semakin tinggi juga insentif yang diberikan.Pemberian insentif bermanfaat baik bagi perusahaan maupun karyawan.Bagi karyawan insentif berfungsi sebagai penyemangat dalam melaksanakan pekerjaan.Untuk mencapai hal tersebut suatu perusahaan harus mampu menciptakan kondisi yang dapat mendorong karyawan untuk mengembangkan dan meningkatkan kemampuan dan keterampilan yang dimilikinya secara optimal. Salah satu cara yang dapat dilakukan perusahaan untuk menciptakan kondisi tersebut adalah dengan memberikan insentif yang memuaskan untuk karyawannya. Sedangkan untuk perusahaan dengan adanya insentif maka mencerminkan upaya perusahaan untuk mempertahankan sumber daya manusia yang dimilikinya dan karyawan juga mempunyai semangat dalam melaksanakan pekerjaannya.

Menurut Terry (Suwatno \& Priansa, 2014) insentif adalah suatu imbalan yang dapat merangsang minat karyawan untuk bekerja. Sedangkan menurut Handoko (Kusuma, 2016) insentif adalah Perangsang yang ditawarkan kepada para karyawan untuk melaksanakan kerja sesuai atau lebih tinggi dari standar-standar yang telah ditetapkan.

Menurut Sarwoto (Suwatno \& Priansa, 2014) indikator insentif adalah sebagai berikut :

1. Insentif material
a. Bonus
b. Komisi
c. Berbagi keuntungan
d. Kompensasi yang ditangguhkan 
2. Insentif non material
a. Pemberian gelar secara resmi
b. Pemberian tanda jasa atau mendali
c. Pemberian piagam penghargaan
d. Pemberian pujian lisan atau tulisan
e. Pemberian promosi
f. Pemberian hak untuk memakai sesuatu atribut jabatan
g. Pemberian perlengkapan khusus pada ruangan bekerja
h. Pemberian hak untuk apabila meninggal dimakamkan pahlawan
i. Ucapan terimakasih secara formal maupun non formal

\section{Komunikasi}

Komunikasi merupakan salah satu fungsi dari manajemen yang penting, karena komunikasi merupakan penyampaian informasi dari seseorang kepada orang lain. Komunikasi juga merupakan pertukaran ide- ide dan informasi dua arah yang menuju tercapainya pengertian bersama.Komunikasi sangat dibutuhkan dalam penyediaan pedoman standar etika perusahaan dan aktivitas yang membentuk kesatuan antara wilayah fungsional dalam bisnis. Komunikasi merupakan penyampaian berbagai macam perasaan, sikap, dan kehendak baik secara langsung maupun tidak langsung baik secara sadar ataupun tidak sadar Yuliyanti, Istiatin, \& Aryati (2017).

Menurut Sopia (Azwar, 2016) komunikasi adalah penyampaian atau pertukaran informasi dari pengirim kepada penerima baik secara lisan, tertuliis maupun menggunakan alat komunikasi. Sedangkan menurut Robbins \& Judge (2008) komunikasi adalah penyampaian pesan dari seseorang kepada orang lain dan pemahaman makna yang disampaikan.

Menurut Siagian (Azwar, 2016) indikator komunikasi adalah sebagai berikut:

1. Tidak mendominasi pembicaraan

2. Menciptakan suasana yang tidak tegang

3. Mendengarkan pendapat karyawan

4. Menghilangkan hal-hal yang dapat mengalihkan perhatian dari pembicaraan yang sedang berlangsung

5. Mampu menempatkan diri pada posisi orang lain

6. Bersikap sabar

7. Mengendalikan emosi 
8. Mencegah timbulnya suasana perdebatan

9. Mengajukan berbagai pertanyaan sebagai bukti perhatian yang diberikan kepada karyawan

\section{Senioritas}

Senioritas berasal dari kata senior, yang menandakan tingkatan perbandingan dari sesuatu terhadap sesuatu yang setara.Senior selalu dihadapkan sebagai lawan kata dari dari junior. Senioritas secara harfiah menurut Kamus Besar Bahasa Indonesia Sari (2015) senioritas diartikan sebagai keadaan yang lebih tinggi dalam hal pangkat, usia dan pengalaman. Menurut Wahyudi (Hamzah, Musadieq, \& Hakam, 2013) Senioritas diartikan sebagai lamanya masa kerja seseorang yang diakui organisasi, baik pada jabatan yang bersangkutan maupun dalam organisasi secara keseluruhan.

Menurut Dessler (Andhara, Utami, \& Mayowan, 2015) indikator senioritas yaitu:

1. Masa kerja

2. Pengalaman kerja

\section{METODOLOGI}

\section{Jenis Penelitian}

Jenis penelitian yang gunakan adalah penelitian asosiatif dan pengolahan datanya menggunakan software SPSS 21.0. Penelitian asosiatif menurut (Sugiono, 2014) merupakan penelitian yang bertujuan untuk mengetahui hubungnan antar dua variabel atau lebih.

\section{Jenis Data}

Jenis data yang digunakan dalam penelitian ini ada dua, yaitu data primer dan data sekunder. Dimana data yang digunakan ini berfungsi untuk membantu penulis dalam melakukan penelitian.

\section{Teknik pengumpulan Data}

\section{Kusioner}

Kusioner yaitu metode pengumpulan data dengan cara menggunakan daftar pertanyaan yang diajukan kepada responden untuk dijawab dengan memberikan angket .menurut Sunyoto (2011) pada umumnya isi materi kusioner meliputi identitas responden dan butirbutir pertanyaan variable penelitian beserta alternative jawaban. Dalam penelitian ini penulis memberikan kuesioner secara langsung kepada karyawan-karyawan Ramayana cabang Kota Tanjungpinang untuk mendapatkan data yang lebih akurat. 


\section{Studi Pustaka}

Dalam studi perpustakaan dilakukan untuk mencari dan mempelajari materi yang berhubungan dengan penelitian yang akan penulis lakukan dengan memahami, mengutip teori-teori dari sejumlah literatur, baik buku, jurnal, maupun karya tulis lainnya yang dapat mendukung dalam penelitian yang dilakukan.

\section{Teknik Penentuan Populasi Dan Sampling}

\section{Populasi}

Menurut Sugiyono (2014) populasi merupakan sebagai daerah yang umum baik itu obyek atau subyek yang mempunyai karateristik tertentu yang ditetapkan sebelumnya oleh peneliti untuk di pelajari dan kemudian dibuat kesimpulannya. Populasi dalam penelitian ini adalah seluruh karyawan Ramayana Department Store Cabang Kota Tanjungpinang.

Tabel 1

Data Jumlah Karyawan Ramayana Cabang Kota Tanjungpinang

\begin{tabular}{|c|l|c|}
\hline No & Jenis Kelamin & Jumlah \\
\hline 1 & Laki-laki & 40 \\
\hline 2 & Perempuan & 74 \\
\hline Total & & 114 \\
\hline
\end{tabular}

Sumber: SDM PT. Ramayana

\section{Sampling}

Menurut Sugiyono (2014) Sampel adalah bagian dari jumlah dan karateristik yang dimiliki oleh populasi tersebut. Pengambilan sampel pada penelitian ini adalah dengan teknik probability sampling yaitu proportionate stratified random sampling dengan menggunakan rumus Slovin.

$$
\begin{aligned}
& n=\frac{N}{1+N e^{2}} \\
& n=\frac{114}{1+114 \cdot(0.05)^{2}}=89
\end{aligned}
$$

Jadi sampel dalam penelitian ini adalah sebanyak 89 orang karyawan Ramayana Departement Store Cabang Kota Tanjungpinang. 


\section{Teknik Analisis Data}

\section{Uji Kualitas Data}

\section{Uji Validitas}

Uji Validitas adalah ketelitian suatu item atau instrument data dalam mengukur apa yang ingin diukur. Hal ini menunjukan adanya dukungan item tersebut dalam mengungkap sesuatu yang ingin diungkap item dikatan valid jika terjadi korelasi yang signifikan dengan skor totalnya. Jika nilai positif dan $r_{\text {hitung }}>r_{\text {tabel }}$ maka item dinyatakan valid. Jika $r_{\text {hitung }}<r_{\text {tabel }}$ maka item dinyatakan tidak Valid (Priyatno, 2012)

\section{Uji Reabilitas}

Menurut Suhaimi (Sunyoto, 2011)Reabilitas terkait pada suatu pengertian bahwa sebentuk instrument cukup bisa dipercaya untuk dapat digunakan sebagai alat pengumpulan data karena instrument tersebut sudah baik. Reabel artinya dapat dipercaya, jadi bisa dan dapat diandalkan. Butir kuesioner dapat dikatakan reabel apabila cronbach's alpha $>0,60$ dan dikatakan tidak reabel apabila cronbach's alpha $<0,60$

\section{Uji Asumsi Klasik}

\section{Uji normalitas}

Uji normalitas untuk menguji apakah nilai residual yang dihasilkan dari regresi terdistribusi secara normal atau tidak.Memiliki nilai residual yang terdistribusi secara normal ialah Model rekresi yang baik (Priyatno, 2012).

Metode yang digunakan adalah metode grafik yaitu melihat menyebar data pada sumber diagonal pada grafik normal P-Plot of regression standardize residual, titik-titik menyebar sekitar garis diagonal maka model regresi memenuhi asumsi normalitas (priyatno, 2012)

\section{Uji Multikolinearitas}

Menurut (Priyatno, 2012), uji multikolinearitas merupakan keadaan terjadinya suatu hubungan linier sempurna atau hampir sempurna antar variable independen dalam model regresi. Dalam hal pengujian multikolinearitas peneliti menggunakan metode tolenrance (TOL) dan Variance Influence Factor (VIF).Dimana jika nilai TOL> 0,10 dan VIF kurang dari 10, maka tidak terjadi masalah multikolinearitas.

\section{Uji Heterokedastisitas}

Menurut (Priyatno, 2012) heterokedastisitas merupakan kondisi dalam model regresi terjadi hal yang tidak sama varian dari residual pada satu pengamatan ke pengamatan yang lain. Model regresi yang baik adalah tidak terjadi heterokedastisitas.Dalam hal pengujian ini 
peneliti menggunakan metode analisis grafik.Dimana jika nilai titik-titik menyebar secara acak dan tidak membentuk pola tertentu, maka tidak terjadi heterokedastisitas.

\section{Uji Autokorelasi}

Model regresi yang baik adalah regresi yang bebas dari autokorelasi. Deteksi adanya autokorelasi dengan melihat besaran Durbin Watson yang secara umum dapat diambil patokan Menurut Priyatno (2012) Pengambilan keputusan pada Uji Durbin Watson sebagai berikut:

1. DU < DW < 4-DU maka Ho diterima, artinya tidak terjadi autokorelasi

2. DW < DL atau DW > 4-DL maka Ho ditolak, artinya terjadi autokorelasi

3. DL < DW < DU atau 4-DU < DW < 4-DL, artinya tidak ada kepastian atau kesimpulan yang pasti.

\section{Regresi Linier Berganda}

\section{Analisis Korelasi Berganda (R)}

Analisis ini digunakan untuk mengetahui hubungan antara variabel indipenden (X1) terhadap variabel dependen $(\mathrm{Y})$

\section{Uji Hipotesis}

\section{Uji Parsial (Uji t)}

Menurut Priyatno (2012) Uji T atau uji koefisien regresi secara parsial digunakan untuk mengetahui apakah secara parsial variabel independen berpengaruh secara signifikan atau tidak terhadap variabel dependen.

\section{Uji Simultan (Uji f)}

Menurut Algifari (Sunyoto, 2013) uji simultan adalah ujikoefisien regresi secara keseluruhan mengetahui ada tidaknya pengaruh yang signifikan antara variabel bebas terhadap variabel terikat.

\section{Uji Regresi Linear Berganda.}

Menurut Priyatno (2012) regresi linear berganda adalahanalisis untuk mengukur besarnya pengaruh antara dua lebih variabel independen terhadap satu variabel dependen dan memprediksi variabel dependen dengan menggunakan veriabel independen.

\section{Analisis Koefisien Determinasi $\left(R^{2}\right)$}

Menurut Priyatno (2012:79) $R$ Square $\left(R^{2}\right)$, yaitu menunjukkan koefisien determinasi. Angka iniakan diubah kebentuk persen, yang artinya persentase sumbangan pengaruh variabel independent terhadap variabel dependent.Adjusted $R$ Square erupakan $R$ Square 
yang telah disesuaikan, yang juga menunjukkan sumbangan pengaruh variabe independent terhadap variabel dependent.Adjusted $R$ Square biasanya digunakan untuk mengukur sumbangan pengaruh jika regresi menggunakan lebih dari dua variabel independent.

\section{PEMBAHASAN}

\section{Uji Validitas}

Uji validitas yang dilakukan dalam penelitian ini adalah sebagai berikut dan dinyatakan valid apabila $r_{\text {hitung }}>r_{\text {tabel. }}$. Dari hasil uji validitas dapat diketahui bahwa semua pertanyaan dalam kuesioner ini dinyatakan valid atau dapat digunakan sebagai instrument dalam penelitian.Dan pertanyaan-pertanyaan yang di ajukan dapat digunakan untuk mengukur variable yang diteliti.

\section{Uji Reliabilitas}

Dalam penelitian ini menggunakan uji reabilitas. Kuesioner dikatakan reliabel jika cronbach's alpha $>0,60$ dan dikatakan tidak reliable apabila jika cronbach's alpha $<0,60$ (Sunyoto, 2011).

\section{Tabel 2}

Hasil Uji Reabilitas

\begin{tabular}{|c|c|c|c|}
\hline Variabel & $\begin{array}{c}\text { Cronbach's } \\
\text { Alpha }\end{array}$ & $\begin{array}{c}\text { Std. } \\
\text { Cronbach's }\end{array}$ & Keterangan \\
\hline Lingliungan Kerja(xl) & 0.872 & 0.60 & Feliabel \\
\hline Insentif (K2) & O. $85 \mathrm{E}$ & 0.60 & Feliabel \\
\hline Komunilaai (K3) & 0.852 & 0.60 & Feliabel \\
\hline Senioritas $(x 4)$ & 0.891 & 0.60 & Faliabel \\
\hline Semangat Keria(r) & 0.843 & 0.60 & Feliabel \\
\hline
\end{tabular}

Sumber: Hasil olahan SPSS 21

Dari hasil data diatas dapat diketahui bahwa semua pertanyaan itu reabel atau dapat dipercaya dilihat dari nilai Cronbach's Alpha $0.685>0,60$. Hal ini berarti bahwa item pernyataan yang digunakan mampu memperoleh data yang diinginkan dalam artian dapat reliable atau dapat dipercaya.

\section{Uji Asumsi Klasik}

Uji Normalitas

Berikut adalah hasil uji normalitas yang didapat dari data yang dikumpulkan melalui penyebaran kuesioner yang dilakukan. 


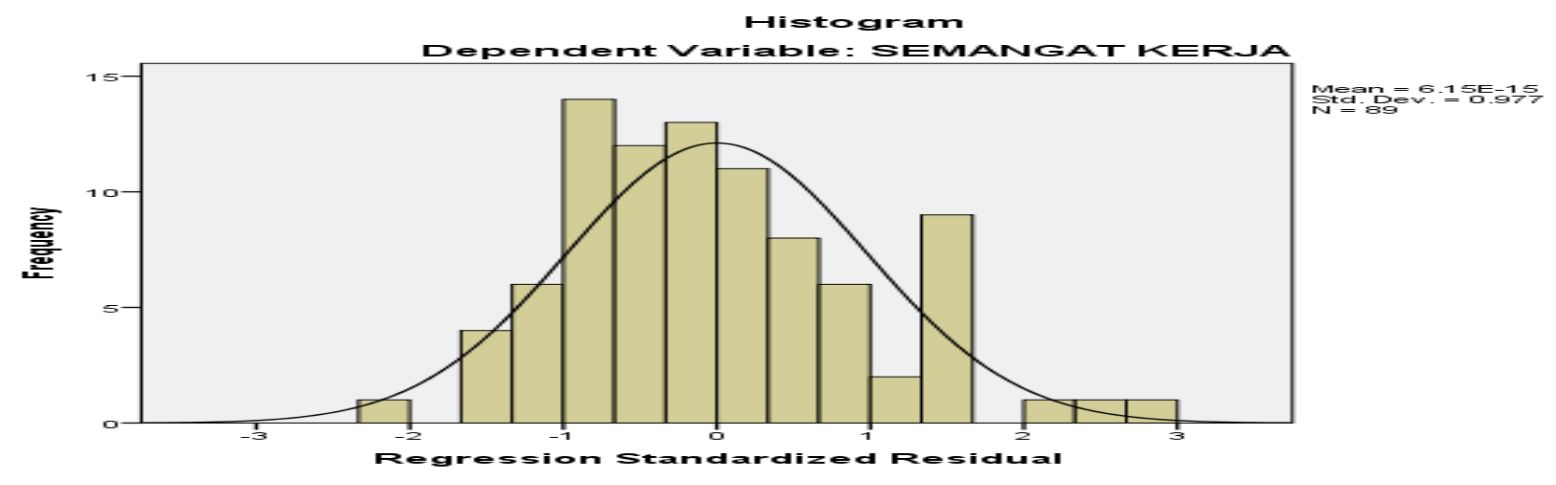

Gambar 1

\section{Uji normalitas Histogram}

Sumber: Hasil Olahan SPSS 21

Pada Gambar 1 dapat dilihat histogram menunjukaan pola distribusi mendekati normal dengan bentuk gambar seperti lonceng, sehingga model regresi memenuhi asumsi normalitas

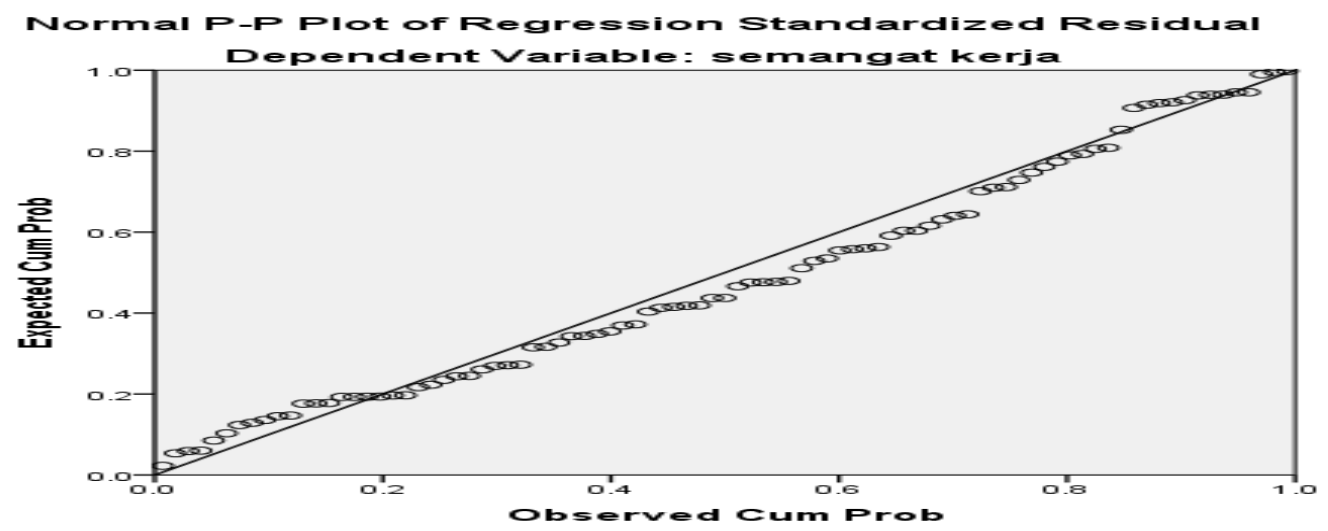

Gambar 2

Uji Normalitas P-plot of Regression Satandardized Residual

Sumber: Hasil olahan SPSS 21

Pada Gambar 2 dapat dilihat bahwa grafik normal probability plot menunjukan plot menyebar disekitar garis normal maka uji asumsi normalitas terpenuhi.

\section{Uji Multikolinearitas}

Berikut adalah hasil uji multikolinearitas yang didapat dari data yang dikumpulkan melalui penyebaran kuesioner yang dilakukan. 
Tabel 3

Uji Multikolinearitas

\begin{tabular}{|c|c|c|c|}
\hline \multirow{2}{*}{\multicolumn{2}{|c|}{ Model }} & \multicolumn{2}{|c|}{ Collinearity Statistica } \\
\hline & & Tolerance & VIF \\
\hline \multirow{5}{*}{1} & (Constant) & & \\
\hline & liglnurgan Heria & .511 & 1.955 \\
\hline & insentif & 482 & 2.076 \\
\hline & homunilsaai & 415 & 2.409 \\
\hline & aenioritas & .582 & 1.717 \\
\hline
\end{tabular}

Sumber: Hasil olahan SPSS 21

Pada Tabel 3 dapat dilihat bahwa hasil yang diperoleh data yang digunakan dalam penelitian ini yaitu variable tidak memenuhi uji multikolinieritas sebab nilai nilai $T O L>0,10$ dan VIF kurang dari 10.

\section{Uji Heterokedastisitas}

Berikut adalah hasil uji eterokedastisitas yang didapat dari data yang dikumpulkan melalui penyebaran kuesioner yang dilakukan.

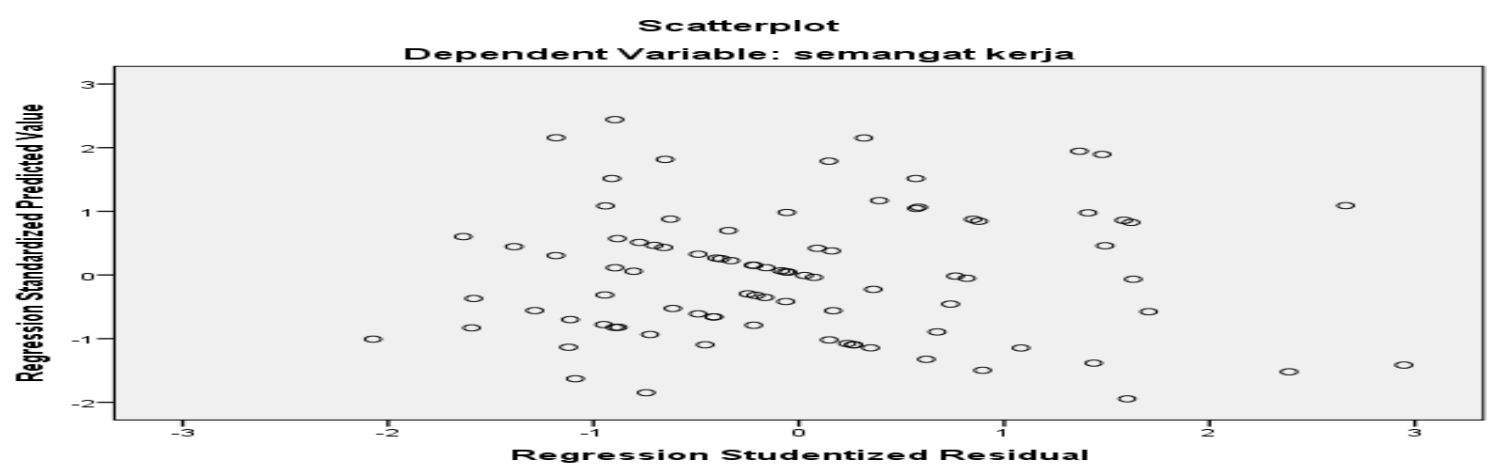

Gambar 3

Uji heterokedastisitas

Sumber: Hasil olahan SPSS 21

Dari gambar diatas terlihat bahwa data yang digunakan dalam penelitian ini didapatkan titik-titik menyebar di atas sumbu $\mathrm{Y}$, jadi kesimpulannya variabel bebas tidak terjadi heterokedastisitas.

\section{Uji Autokorelasi}

Berikut adalah hasil uji autokorelasi yang didapat dari data yang dikumpulkan melalui penyebaran kuesioner yang dilakukan. 
Tabel 4

Uji Autokorelasi

\begin{tabular}{|c|c|c|c|}
\hline \multicolumn{4}{|c|}{ Mode Summiry" } \\
\hline \multirow[t]{2}{*}{ Model } & \multicolumn{2}{|c|}{ Chese Statiotice } & Duitil: \\
\hline & $d 2$ & Sile Flane & Widon \\
\hline 1 & $84^{4}$ & W & 2.49 \\
\hline
\end{tabular}

Sumber: Hasil olahan SPSS 21

Nilai Durbin Watson sebesar 2.043.sedangkan tabel DW dengan Signifikansi 0.05 dan jumlah data $(\mathrm{n})=89 \mathrm{~K}=4$ (jumlah variabel), diperoleh nilai DL 1.563 dan DU 1.750. Jadi 4$\mathrm{DU}=2.25$ dan 4-DL= 2.437. Maka dari hasil tersebut dapat diperoleh $\mathrm{DU}<\mathrm{DW}<4$-DU dengan nilai $1.750<2.043<2.25$ maka Ho diterima, artinya tidak terjadi autokorelasi

\section{Regresi Linear Berganda}

\section{Analisis Korelasi Berganda (R)}

Hasil dari data yang di uji dengan menggunakan SPSS 21 untuk mencari analisis korelasi berganda adalah sebagai berikut:

Tabel 5

Hasil Anaisis Korelasi Berganda

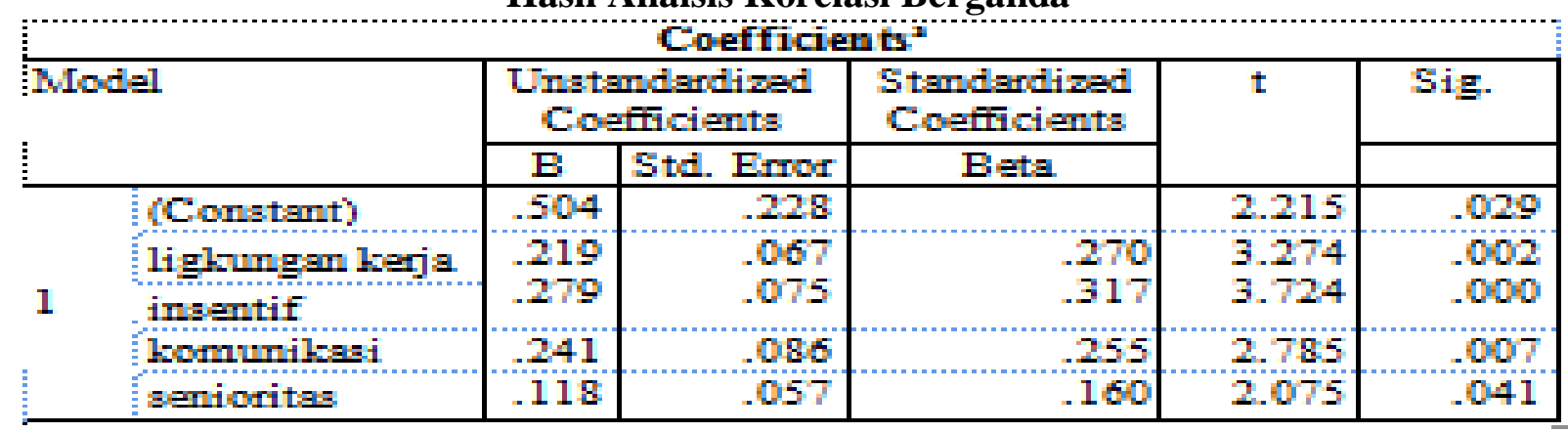

Sumber: Hasil olahan SPSS 21

$\mathrm{Y}=(0.504)+(0.219) \times 1+(0.279) \times 2+\quad(0.241) \times 3+(0.118) \times 3$

Persamaan regresi di atas yaitu:

$\mathrm{a}=0.504$ menunjukan bahwa jika $\mathrm{x}$ (lingkungan kerja, insentif, komunikasi, dan senioritas) konstan atau $\mathrm{x}=0$, maka semangat kerja karyawan sebesar 0.504 .

$\mathrm{b}=0.219$ menunjukan setiap perubahan satu variable lingkungan kerja akan mengurangi semangat kerja karyawan sebesar 0.219 
$\mathrm{c}=0.279$ menunjukan setiap perubahan satu variable insentif akan mengurangi semangat kerja karyawan sebesar 0.79

$\mathrm{d}=0.241$ menunjukan setiap perubahan satu variable komunikasi akan mengurangi semangat kerja karyawan sebesar 0.241

$\mathrm{e}=0.118$ menunjukan setiap perubahan satu variable senioritas akan mengurangi semangat kerja karyawan sebesar 0.118

\section{Uji Hipotesis}

\section{Uji Parsial (uji-T)}

Berikut adalah hasil uji parsial (uji-T) yang didapat dari data yang dikumpulkan melalui penyebaran kuesioner yang dilakukan.

Tabel 6

Hasil Uji Parsial (uji-T)

\begin{tabular}{|c|c|c|c|c|c|c|}
\hline & \multirow{2}{*}{ Model } & \multicolumn{2}{|c|}{$\begin{array}{c}\text { Unstandardized } \\
\text { Cosfificienta }\end{array}$} & \multirow{2}{*}{$\begin{array}{c}\text { Standandized } \\
\text { Cosificient: } \\
\text { Beta }\end{array}$} & \multirow{2}{*}{$\mathrm{t}$} & \multirow[t]{2}{*}{ Sig. } \\
\hline & & $\mathrm{B}$ & $\begin{array}{l}\text { Std. } \\
\text { Error }\end{array}$ & & & \\
\hline \multirow{5}{*}{1} & (Constant) & .504 & 228 & & 2.215 & .029 \\
\hline & lighungan heria & 219 & 067 & 270 & 3.274 & 002 \\
\hline & insertif & 279 & .075 & .317 & 3.724 & .000 \\
\hline & lomunileasi & 241 & .086 & 255 & 2.785 & .007 \\
\hline & Benioritas & .118 & .057 & .160 & 2.075 & .041 \\
\hline
\end{tabular}

Sumber: Hasil olahan SPSS 21

Tabel distribusi t dicari pada $\alpha=5 \%$, dengan derajat kebebasan (df) $n=k-1$ atau 89-4-1 $=84$ ( $\mathrm{n}$ jumlah data dan $\mathrm{k}$ adalah jumlah vareabel independen). Dengan pengujian 2 sisi hasil untuk nilai $t_{\text {tabel }}$ sebesar 1.988.kesimpuan yang dapat diambil yaitu bahwa nilai $t_{\text {hitung }}$ semua variabel independen (lingkungan kerja, insentif, komunikasi, dan senioritas) $>t_{\text {tabe }}$ maka dapat dipastikan bahwa masing-masing variabel independen berpengaruh secara parsial terhadap variabel dependen (semaangat kerja)

\section{Uji Simultan (uji-F)}

Berikut adalah hasil uji simultan (uji-F) yang didapat dari data yang dikumpulkan melalui penyebaran kuesioner yang dilakukan. 
Tabel 7

Hasil Uji Simultan (uji-F)

\begin{tabular}{|c|c|c|c|c|c|c|}
\hline \multirow{2}{*}{\multicolumn{2}{|c|}{ Model }} & \multicolumn{3}{|c|}{ ANOVA } & \multirow[b]{2}{*}{$\bar{F}$} & \multirow[b]{2}{*}{ Sig. } \\
\hline & & $\begin{array}{l}\text { Sum of } \\
\text { Squares }\end{array}$ & df & $\begin{array}{l}\text { Mean } \\
\text { Square }\end{array}$ & & \\
\hline \multirow{3}{*}{1} & Fepresion & 8.232 & 4 & 2.058 & 50.845 & $.000^{\circ}$ \\
\hline & Residual & 3.400 & 84 & .040 & & \\
\hline & 'Tot:al & 11.632 & $\mathrm{BB}$ & & & \\
\hline
\end{tabular}

Sumber: Hasil Olahan SPSS 21

Berdasarkan hasil olahan SPSS didapat nilai $F_{\text {hitung }}>F_{\text {tabel }}(50.845>2.71)$ dengan hipotesis Ho ditolak dan Ha diterima. Sehingga dapa disimpulkan bahwa variabel bebas (lingkungan kerja, insentif, komunikasi, dan senioritas ) secara bersama-sama berpengaruh terhadap variabel semangat kerja.

\section{Koefisien Determinasi $\left(\mathbf{R}^{2}\right)$}

Berikut adalah hasil uji koefisien determinasi yang dilakukan dalam penelitian ini.

Tabel 8

\section{Koefisien Determinasi}

\begin{tabular}{|l|r|r|r|r|}
\hline Model & R & R Square & $\begin{array}{c}\text { Adjusted R. } \\
\text { Square }\end{array}$ & $\begin{array}{c}\text { Std. Error of the } \\
\text { Estimate }\end{array}$ \\
\hline 1 & $.841^{2}$ & .708 & .604 & \\
\hline
\end{tabular}

Sumber: Hasil Olahan SPSS 21

Berdasarkan hasil Tabel 8 tersebut menunjukan koefisien determinasi atau adjusted $\mathrm{R}$ square sebesar 0,694 (69.4\%). Angka tersebut menunjukan bahwa variabel independen yaitu lingkungan kerja, insentif, komunikasi, dan senioritas memberi sumbangan pengaruh pada variabel dependen ( semangat kerja) sebesar 69.4\% sedangkan sisanya 30.6\% (100\% $69.4 \%$ ) dipengaruhi oleh variabel lainnya yang tidak diteliti pada penelitian ini misalnya motivasi kerja, kompensasi dan tingkat kesejahteraan. Sedangkan hubungan (R) lingkungan kerja, insentif, komunikasi dan senioritas (X) terhadap semangat kerja (Y) sebesar 0.708. 


\section{KESIMPULAN DAN SARAN}

\section{Kesimpulan}

Dari hasil penelitian dapat disimpulkan bahwa:

1. Lingkungan kerja, insentif, komunikasi, dan senioritas berpengaruh secara parsial dan simultan terhadap semangat kerja karyawan dilihat dari variabel lingkungan kerja yang memiliki nilai $t_{\text {hitung }}>t_{\text {tabel }}(3.274>1.988)$, kemudian variabel insentif memilihi nilai $t_{\text {hitung }}>\mathrm{t}_{\text {tabel }}(3.724>1.988)$, dan variabel komunikasi memiliki nilai $t_{\text {hitung }}>t_{\text {tabel }}$ $(2.785>1.988)$, dan variabel Senioritas memiliki nilai $t_{\text {hitung }}>t_{\text {tabel }}(2.075>1.988)$.

2. Berdasarkan pengujian simultan ternyata hasil penelitian menunjukan nilai $F_{\text {hitung }}$ sebesar 50.845, nilai $F_{\text {tabel }}$ sebesar karena nilai $F_{\text {hitung }}>F_{\text {tabel }}(50.845>2.71)$ sehingga dapat disimpulkan bahwa variabel bebas (lingkungan kerja, insentif, komunikasi dan senioritas) secara bersama-sama berpengaruh terhadap semangat kerja karyawan Ramayana Departement Store Cabang Kota Tanjungpinang.

3. Hasil pengujian determinasi $\left(\mathrm{R}^{2}\right)$ menunjukan bahwa nilai adjusted $\mathrm{R}$ sequare koefisien determinasinya $=0.694(69.4 \%)$. Angka tersebut menunjukan bahwa variabel independen yaitu lingkungan kerja, insentif, komunikasi, dan senioritas memberi sumbangan pengaruh kepada variabel dependen yaitu semangat kerja sebesar $69.4 \%$ sedangkan sisanya 30.6\% dipengaruhi oleh variabel lainnya yang tidak diteliti dalam penelitiaan ini. $\left(\mathrm{R}^{2}\right)$ sebesar 0,694 yang menunjukan bawa sebesar 69,4\% semangat kerja dipengaruhi oleh variable lingkungan kerja, insentif, komunikasi, senioritas sedangkan sisanya 30,6\% dipengaruhi oleh variabel lainnya.

\section{Saran}

Berdasarkan hasil penelitian, maka dapat disampaikan saran sebagai berikut:

1. Perusahaan hendaknya memperbaiki lingkungan kerja dengan menambah sarana prasarana yang lebih baik.

2. Untuk meningkatkan semangat kerja karyawan, maka perusahaan harus memperbaiki insentif yang diberikan dari waktu ke waktu.

3. Komunikasi sangat penting untuk meningkatkan semangat kerja karyawan, oleh karena itu komunikasi harus diperbaiki dan ditingkatkan.

4. Senioritas sangat perlu dipertimbangkan agar semangat kerja karyawan senantiasa terjaga, namun yang senior harus memberikan contoh yang baik dan kinerja yang baik pada yang karyawan yang lain. 
5. Semangat kerja harus ditingkatkan melalui lingkungan kerja yang nyaman, insentif yang lebih baik, komunikasi yang lebih baik, dan memperhatikan senioritas.

\section{REFERENSI}

Andhara, S. De, Utami, H. N., \& Mayowan, Y. (2015). Pengaruh Senioritas Dan Loyalitas Terhadap Promosi Jabatan ( Studi pada Karyawan Departemen Kebijakan Ekonomi dan Moneter Bank Indonesia Jakarta ) Abstrak. Jurnal Administrasi Bisnis (JAB), 22(1), 19.

Azwar, M. S. (2016). Pengaruh gaya kepemimpinan, komunikasi, dan disiplin kerja terhadap kinerja karyawan. Jurnal Ilmu Dan Riset Manajemen, 5(3), 1-20.

Hamzah, F. M., Musadieq, M. Al, \& Hakam, M. S. (2013). Pengaruh Senioritas dan Loyalitas terhadap promosi (Studi Pada Karyawan PT. Pembangunan Perumahan DVO III Surabaya). Jurnal Administrasi Bisnis (JAB), 6(2), 1-8.

Jain, R., \& Kaur, S. (2014). Impact Of Work Environment On Job Satisfaction. International Journal of Scientific and Research Publications, 4(1), 1-8.

Kusuma, Y. W. (2016). Pengaruh Motivasi Kerja Dan Insentif Terhadap Semangat Kerja Karyawan CV, F.A Management. Jurnal Ilmu Dan Riset Manajemen, 5(2).

Nitisemito, A. (2010). Manajemen Personalia (Edisi Kede). Jakarta: Ghalia Indonesia.

Priyatno, duwi. (2012). Cara Kilat Belajar Analisis Data Dengan SPSS 20. Yogyakarta: CV. Andi Offset.

Robbins, S. P., \& Judge, T. A. (2008). Perilaku Organisasi Edisi 12. Jakarta: Salemba Empat.

Saputra, H., Hendriani, S., \& Amsal, C. (2014). Pengaruh Kompensasi dan Lingkungan Kerja Terhadap Semangat Kerja Karyawan pada PT. Bina Sawit Nusantara (BSN) Pekanbaru. JOM FEKON, 1(2), 1-16.

Sari, D. C. (2015). Pengaruh Lingkungan Kerja Dan Senioritas Terhadap Produktivitas Kerja Dosen Di Jurusan Administrasi Niaga Politeknik Negeri Medan. Jurnal Ilmiah Research Sains, 1(3).

Sugiono. (2014). Metode Penelitian Administrasi Dilengkapi Dengan Metode $R \& D$. Bandung: Alfabeta.

Sunyoto, D. (2011). Metodologi Penelitiana Untuk Ekonomi. Yogyakarta: CAPS.

Suwatno, D., \& Priansa, J. (2014). Manajemen SDM Dalam Organisasi Publik Dan Bisnis. 
Bandung: CV. Alfabeta.

Tulenan, S. (2015). The Effect Of Work Environment And Compensation Toward Employee Performance At The Office Of State Assets And Auction Service Manado. Jurnal EMBA, 3(3), 672-682.

Widani, N. L. S. (2017). Pengaruh Kompensasi Dan Komunikasi Terhadap Semangat Kerja Karyawan Pada Hotel Puri Dajuma Resort. E-Journal Jurusan Pendidikan Ekonomi, $10(2)$.

Yuliyanti, Y., Istiatin, \& Aryati, I. (2017). Pengaruh Insentif, Disiplin Kerja, Dan Komunikasi Terhadap Kinerja Karyawan Bagian Sewing PT. Pelita Tomangmas Karanganyar. Jurnal Akuntansi Dan Pajak, 18(1), 145-157. 